\title{
Community's Perspectives on the Attendance of Rohingyas in Aceh
}

\author{
Malahayati Rahman ${ }^{1, *}$ \\ ${ }^{1}$ Universitas Malikussaleh \\ *Corresponding author.Email: malahayati@unimal.ac.id
}

\begin{abstract}
This paper aims to describe the Indonesian people's perspective towards Rohingya refugees' presence in Aceh in June 2020. This study uses a mix-method approach to obtain primary data. Data were collected by distributing an online questionnaire to all society components, especially those interested in the Rohingya refugees' issue. We received 267 responses within two weeks, followed by Indonesian respondents aged 19 to 60 , with diverse occupational backgrounds. The results showed that most of the community (87.6\%) accepted Rohingya refugees back to Aceh, $10.9 \%$ refused, and $1.5 \%$ abstained. The Indonesian people take Rohingya refugees based on religious thought (44\%), on humanity reason (35\%), on morality reason (14\%), legality (3\%), and others (4\%). Meanwhile, for those who refused Rohingya refugees, the economic, social, health, and regulatory problems were found as the reasons. The positive acceptance of the Indonesian people for Rohingya refugees should be a consideration for the Government in formulating policies related to the handling of Rohingya refugees in Indonesia. For this reason, the Government should encourage socialization, coordination, and community participation in overcoming the problems of Rohingya refugees in Aceh by using a religious approach and local wisdom.
\end{abstract}

Keywords: Religious Approach, Local Wisdom, Humanity, Morality

\section{INTRODUCTION}

This paper will describe the Indonesian people's perspective, especially in Aceh, towards Rohingya refugees' return in 2020. Acehnese are quite familiar with Rohingyas because they have often been stranded in the ocean connected to the Aceh coast. Even though the Indonesian Government refused their presence, fishers and Aceh's people, on their initiative, helped their stranded boat be saved on land.

The most significant Rohingya inflows occurred during the 2015 Andaman Sea crisis when thousands of people were stranded at sea [1]. The Indonesian Government tends not to provide much assistance to them and only provides humanitarian assistance and submits it to UNHCR to be placed in a third country or returned to the country of origin [2].

On the other hand, Indonesians provide limited but much-needed assistance to Rohingya refugees. In two incidents in April 2018, Acehnese fishers rescued 84 Rohingyas who were stranded at sea but were rejected by the Indonesian and Malaysian governments [3]. Likewise, what happened in the stranding incident of 99
Rohingya refugees on 24 June 2020 [4] or 297 Rohingya on 7 September 2020 [5].

The presence of Rohingyas during the Pandemic has become a dilemma for the Government of Indonesia and its community. Various opinions are scattered in social media, public discussions, and discussions among academics. For this reason, it is essential to find out more about the perspective of the community on the return of Rohingya refugees in Aceh in 2020.

Hopefully, this survey results can be an input for all stakeholders in formulating technical policies for handling refugees from abroad. Theoretically, these findings can contribute to scientific development, both legally, economically, and socially.

\section{METHODS}

The research conducted a survey on the perspective of the Indonesian people towards Rohingya refugees and their presence in Aceh. The survey took place in June 2020, when a wave of Rohingya refugees returned to Aceh for the umpteenth time. 
We collected data through online questionnaires distributed to various groups of people, divided into age groups, place of residence, religion, and occupation. The collected responses were 267 responses. The questionnaire consisted of 11 questions related to people's perspectives on Rohingyas' return to Aceh. There are three open-ended questions and eight semiopen questions, providing several alternative answer choices.

Then we inputted data in the google form. All data were then verified, clustered, coded, and described qualitatively using the NVivo application. The author then analyzes the data using a religious approach and local wisdom.

\section{RESULTS}

\subsection{Geographical Data}

Aceh is one area that is often used as a temporary shelter for Rohingya refugees. They were initially stranded in nearby waters and rescued by Acehnese fishermen. Aceh's position as a transit area in the Malacca Strait is very strategic.

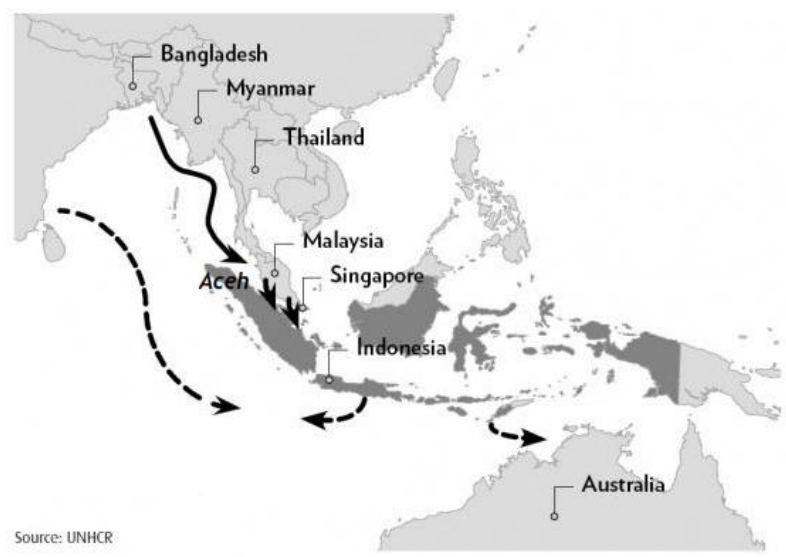

Figure 1: Aceh and the Strait of Malacca

The Strait is the main waterway between the Pacific Ocean and the Indian Ocean, linking three of the world's most populous nations China, India, and Indonesia as well as linking the regions west of the Strait with economic powerhouses such as China, Japan, and South Korea [6]

\subsection{Respondent}

Respondents who took part in the survey totalled 267. The people who became respondents were divided into age groups, place of residence, religion, and occupation. Respondent categories based on religious group and age can be seen in the figure below:

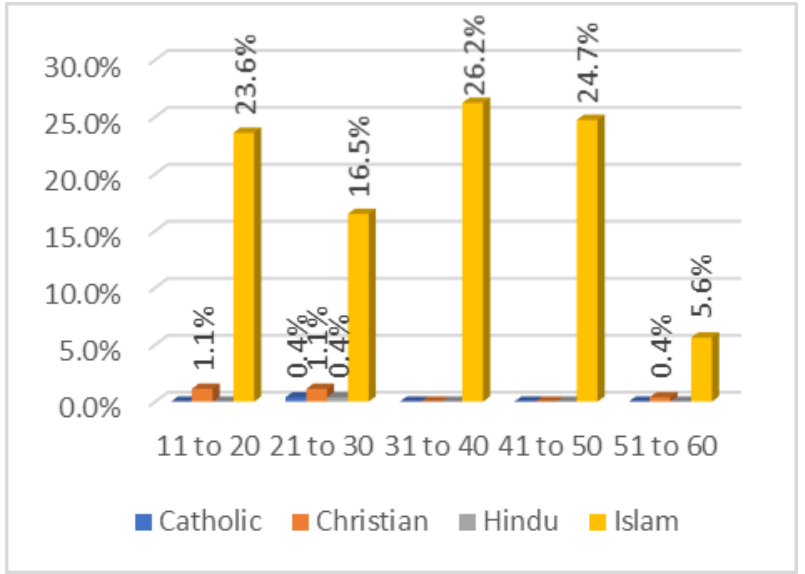

Figure 2: Age \& Religions of Respondents

The distribution of respondents based on the criteria for residence and work is illustrated in the figure below:

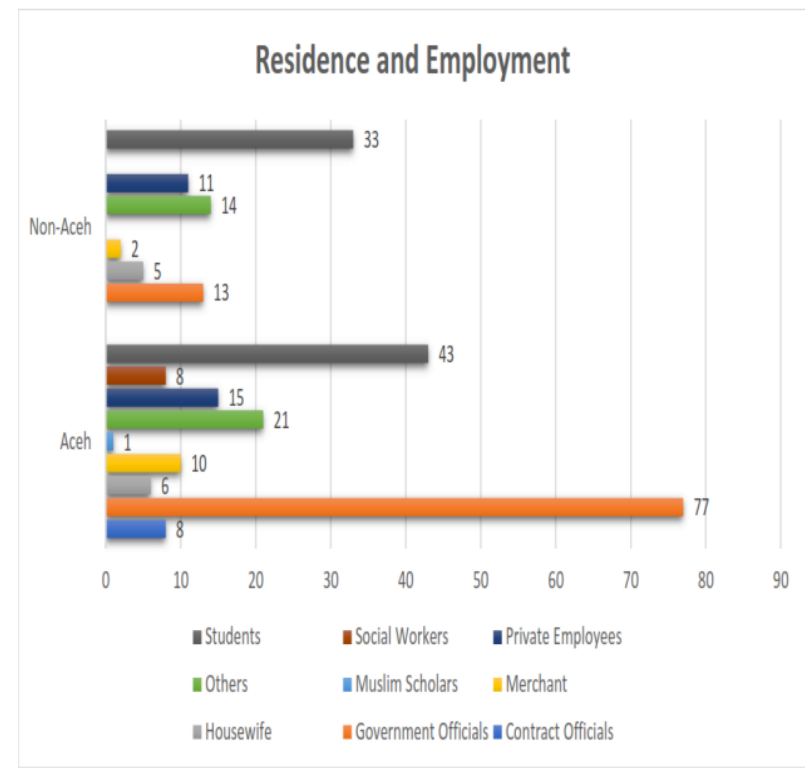

Figure 3: Respondents' Residence and Employment

\subsection{Community Perspective on Rohingyas}

Community's perspectives on Rohingya's presence in Aceh are divided based on the category of residence, religion, age, and occupation. Generally, it can be seen in the figure below:

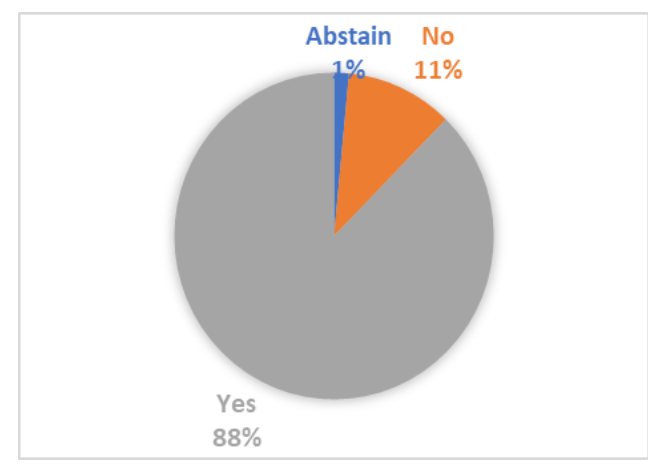

Figure 4: Perspective of Society 
However, the community mostly accepted the presence of Rohingya in Aceh for a temporary period. Of the 234 respondents who accepted, only 38 respondents (16.2\%) could accept Rohingya as permanent residents. The rest of the respondents only received for not more than one year $(11.6 \%)$, between 1 5 years $(0.9 \%)$ or without an exact time limit, and depending on the Rohingya conditions, it was possible to be returned or sent to a third recipient country ( $71.3 \%)$.

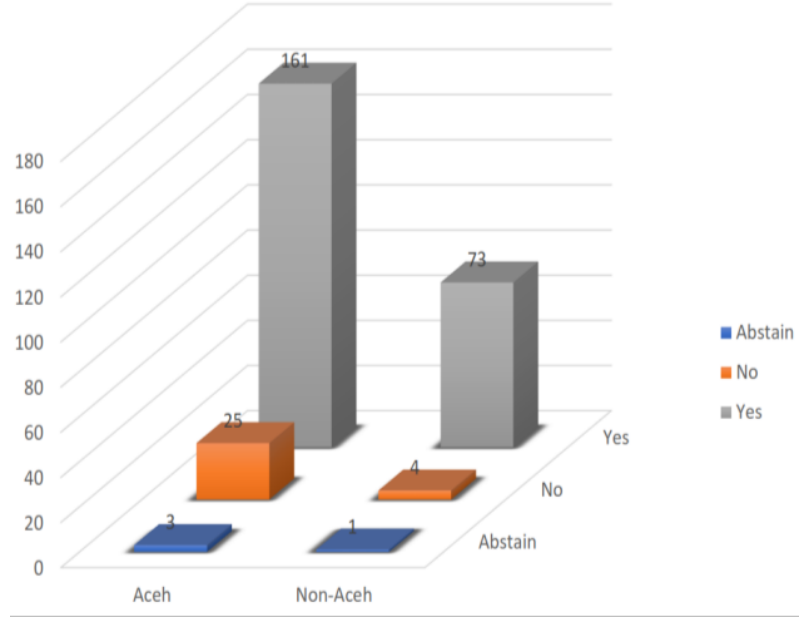

Figure 5: Perspective Based on Residence

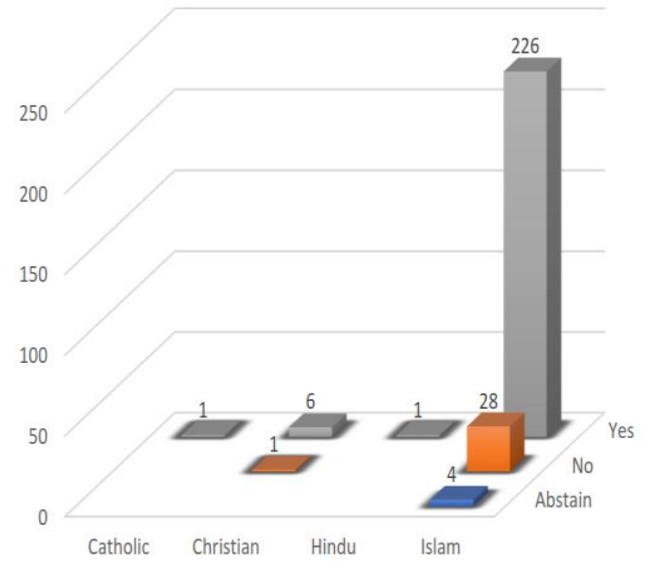

Figure 6: Perspective Based on Religions

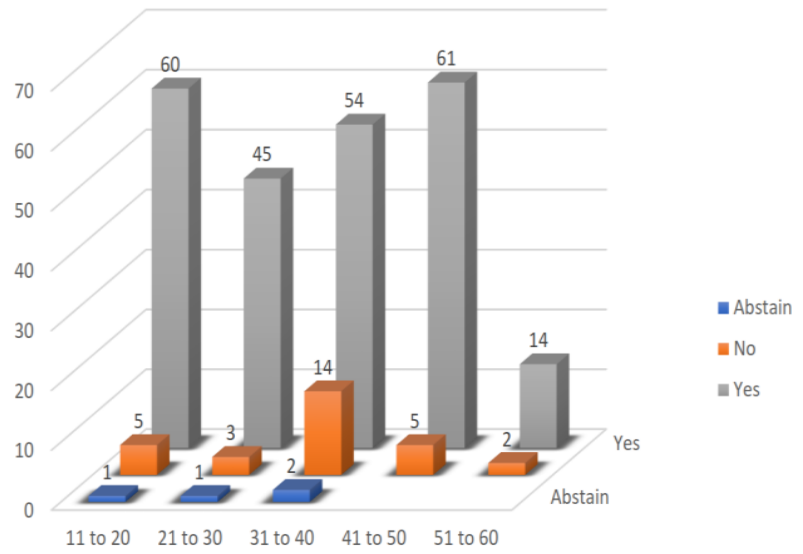

Figure 7: Perspective Based on Ages

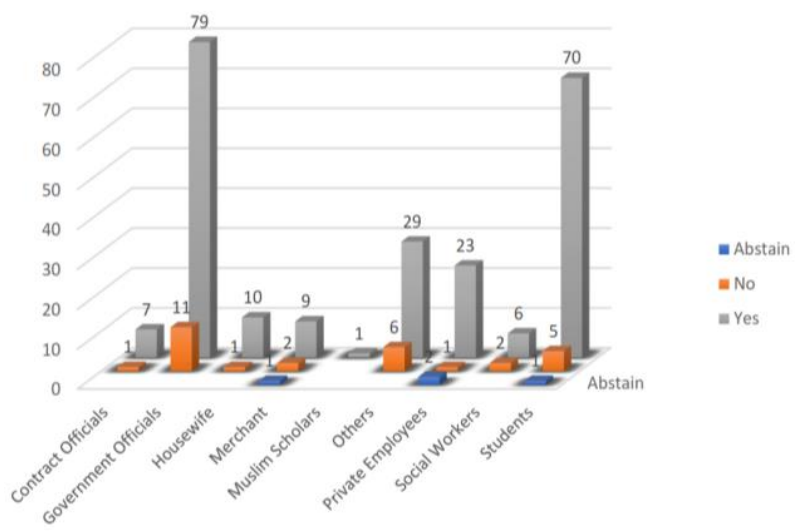

Figure 8: Perspective Based on Employment

Meanwhile, the respondents' reasons for accepting Rohingyas can be categorized into several groups, namely for reasons of religious morality, religious humanity, religious brotherhood, humanity, legality, morality, and others, as seen in figure 9 below:

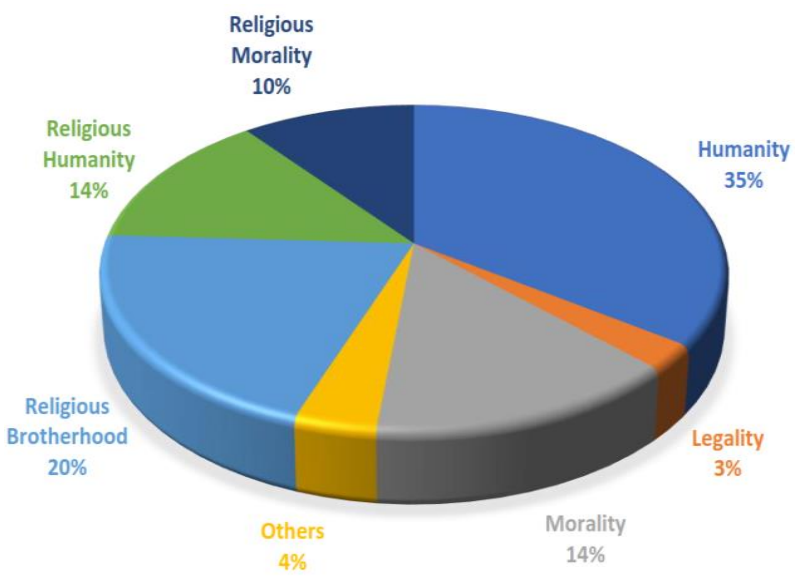

Figure 9: Reasons for Acceptance

The rejection occurs due to reasons of health problems, economic problems, regulations problems, social problems, and others, as illustrated in Figure 10:

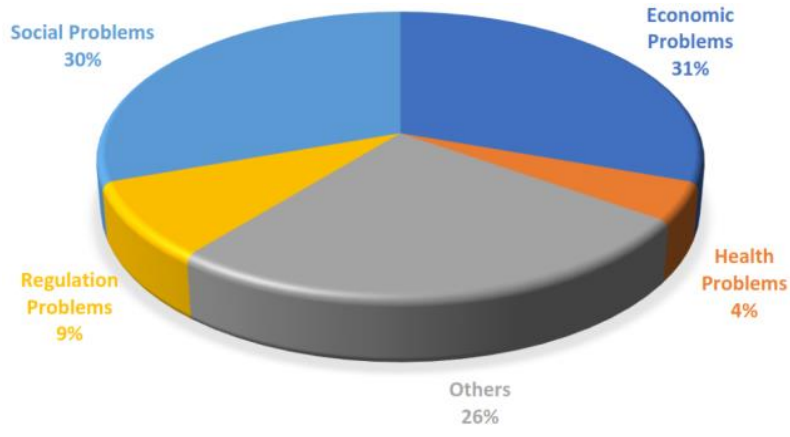

Figure 10: Reasons for Rejection

\section{DISCUSSION AND CONCLUSION}

In general, the Indonesian people accept the return of Rohingya refugees in Aceh (Figure 4). It can be seen 
in each respondent category, namely residence, religion, age, and occupation.

There is no significant difference in the percentage of acceptance from Aceh Province residents than residents outside Aceh. Of the 189 respondents in Aceh, $85.2 \%$ agreed to take back Rohingya refugees in Aceh. Meanwhile, of the 78 respondents outside Aceh Province, 93.6\% agreed to accept Rohingya refugees. From these criteria, we concluded that respondents' residency does not have a significant effect on the acceptance of Rohingya refugees in Aceh.

The highest number of admissions was 41-50 yo in the age category, followed by 11-20 yo, and 31-40 yo. However, in the age group under 20 to 40 years of age, there was an abstention response to Rohingya's presence. The highest rejection rate is at the age of 3140 years, which is the workforce's age. It could be attributed to the rejection of the emergence of economic problems for the indigenous population. The economic problems of the people in the country, especially in Aceh, are still quite difficult. They suggested that the aid funds given to Rohingya refugees should be used to recover the local community's economy, especially during this Pandemic.

The community's acceptance of Rohingya refugees is mainly due to religious reasons (44\%). The reasons for religious teachings based on humanitarian principles (14\%), morality (10\%), and Islamic brotherhood or Ukhuwah Islamiyah (20\%) are reasons for Muslims to accept Rohingya back in Indonesia, especially in Aceh (Figure 9). This view is inseparable from the religious influence of the Rohingya refugees themselves. The majority of respondents considered that Rohingya were obliged to be assisted because, as fellow Muslims, they were like one body. If some Muslims are in trouble, other Muslims must help them as best they can. Rohingya refugees are believed to be Muslims who have had to leave their homes because they were persecuted based on their religion.

Meanwhile, a more secular view considers acceptance of Rohingya refugees as part of legal obligations (3\%), moral obligations (14\%), and obligations as fellow human beings $(35 \%)$.

On the other hand, the community's rejection of Rohingya refugees also has its reasons, primarily influenced by the respondents' experiences during the time that Rohingya refugees were temporarily accommodated in Aceh and Indonesia. Respondents also consider health problems, economic problems, regulation problems, and social problems in refusing Rohingyas in Aceh (Figure 10).

The Covid-19 Pandemic condition made the community worried that the Rohingya group would bring the outbreak to the Aceh region. This reason is unreasonable, considering that the refugees have been in the ocean for approximately three months. With that period, it can be sure they are sterile from Covid-19.

Regulatory issues have also become a consideration for some respondents to reject the presence of refugees in Aceh. Even though Presidential Regulation Number 125 of 2016 concerning Handling of Refugees from Abroad has been issued, practically it has not been maximally implemented by the Government of the Republic of Indonesia.

Social problems are also considered to be one of the potential problems that will occur if Rohingyas are accepted in Aceh. The experience of temporary shelter for Rohingya refugees in Aceh has caused several social cases, such as social jealousy, differences in character, customs, and lack of language to communicate.

Based on the community's reasons for refusing or accepting Rohingya refugees back in Indonesia, especially in Aceh, the Government needs to consider technical arrangements based on local wisdom and religious values to handle Rohingya refugees who have been stranded and rescued in Aceh. The coordination and synergy of the Central Government, Regional Government, indigenous peoples, and local communities need to be continuously improved. Although Indonesia has not signed the 1951 Convention on the Status of Refugees, Indonesia still should protect refugees based on humanity and morality as civilized nations in the world.

\section{AUTHOR'S CONTRIBUTIONS}

Malahayati conceived of the presented idea, wrote the manuscript, reviewed and finalised it.

\section{ACKNOWLEDGMENTS}

The author would like to thank the Faculty of Law and the Institute for Research and Community Service at the University of Malikussaleh, who have provided support for the 2019 PNBP Research Grant. This research was carried out as part of the collaboration between the Faculty of Law, University of Malikussaleh, and the Law Faculty of Universiti Kebangsaan Malaysia. This research was conducted with our colleague, Laila M. Rasyid, S.H., M.Hum., Ferdy Saputra S.H., M.H., and Dr. Muhammad Nasir, S.H., LL.M., who have helped with data collection in Aceh - Indonesia, and Malaysia.

\section{REFERENCES}

[1] "Ratusan pengungsi Rohingya di Aceh bergantung pada bantuan - BBC News Indonesia." https://www.bbc.com/indonesia/berita_indonesia/2 015/05/150515_indonesia_rohingya_cangkoi (accessed Nov. 04, 2020).

[2] H. Alunaza and M. K. Juani, "Kebijakan 
Pemerintah Indonesia melalui Sekuritisasi Migrasi Pengungsi Rohingya di Aceh tahun 2012-2015," Indones. Perspect., 2017, doi: 10.14710/ip.v2i1.15535.

[3] "Nelayan Indonesia selamatkan pengungsi Rohingya - UNHCR Indonesia." https://www.unhcr.org/id/11528-nelayanindonesia-menyelamatkan-rohingya.html (accessed Nov. 04, 2020).

[4] "Menlu RI: 99 Orang Rohingya di Aceh Resmi Berstatus Pengungsi." https://www.voaindonesia.com/a/menlu-99-orangrohingya-di-aceh-resmi-berstatuspengungsi/5514394.html (accessed Nov. 04, 2020).

[5] "Ratusan Pengungsi Rohingya Membutuhkan Bantuan Darurat Anda - UNHCR Indonesia." https://www.unhcr.org/id/13173-ratusanpengungsi-rohingya-membutuhkan-bantuandarurat-anda.html (accessed Nov. 04, 2020).

[6] H. . Ibrahim and N. Khalid, "Growing Shipping Traffic in the Strait of Malacca: Some Reflections on the Environmental Impact," Marit. Inst. Malaysia, 2007. 